\title{
READ AS/WITH THE PERPETRATOR: MANASSEH'S VULNERABILITY IN 2 KINGS 21:1-18 AND 2 CHRONICLES 33:1-20
}

Gerrie F. Snyman

University of South Africa

\begin{abstract}
This essay explores Manasseh's vulnerability in both narratives in terms of the current reader's own vulnerability. In 2 Kings 21:1-18 Manasseh appears to remain invulnerable over-against the inhabitants of Jerusalem's vulnerability. In 2 Chronicles 33:1-20 Manasseh is turned fragile in captivity and physically rendered vulnerable. The essay is divided into three sections. It starts with a theoretical basis for the argument of vulnerability, following Levinas' ethical moment, discussing the notion of vulnerability as a negative state, and constructing vulnerability as possibility on the basis of Erinn Gilson's book, The Ethics of Vulnerability. A Feminist Analysis of Social Life and Practice. In the second part Manasseh's story in 2 Kings 21:1-18 and 2 Chronicles 33:1-20 is analyzed and in the last part the author connects the notion of vulnerability to these two stories.
\end{abstract}

Key Words: Vulnerability; Manasseh; Persian Period; Contextual Study; Exile

\section{Introduction}

It is common knowledge that in the Book of Kings Manasseh receives no redemption, whereas the Book of Chronicles provides redemption in the form of building projects and religious reforms. The question is on what basis redemption is provided. I will argue that redemption happened the moment Manasseh rendered himself vulnerable. It seems vulnerability only appears in the face of calamity: publicly humiliated by being caught by hooks, chained in bronze fetters and deported to Babylon, Manasseh faced a miserable life as prisoner of the Assyrians.

The Judeo-Christian tradition sees the human being as the bearer of dignity and rights. Human dignity is based on the notion of being created in the image of the deity. Creation in the image of the deity results in human vulnerability that is positioned against divine invulnerability. It is as if "every entity in the world is vulnerable except for God." Joseph Tham argues and asks, "Clearly there is a tendency in the Bible to see imperfection or disease as the result of sin. Nevertheless, is absolute perfection the ideal to strive for? Isn't imperfection a fact of life?"2 To Tham, imperfection is part of the vulnerable condition of the human being. It is 'built into' human nature and it would be hubris to ignore it.

As a white male South African biblical scholar, the current socio-political context requires me to acknowledge openly my racist and patriarchal upbringing and subsequent privileges in perpetrator culture. The critique of white patriarchy is very public, its effects no longer masked because of the de-colonial project. Thus, in any reading of the biblical text, I am publicly obliged to render myself vulnerable in order to face those aspects of oppression that would previously have been masked. Manasseh's hooks and fetters have become my silence and introspection in a process of embarrassment and internalising the critique. 
What good comes from reading as/with a perpetrator? Usually, once indicated, a perpetrator is removed from the scene, sometimes very publicly. I have found that reading the biblical text as/with a perpetrator renders one extremely vulnerable. To make it beneficial it needs to be turned into an instance from which change can occur - a redemptive moment.

Hendrik Bosman recently asked the following concluding question in an essay on Old Testament Scholarship in South Africa since 1994:

How can 'organic intellectuals' maintain a self-critical awareness of the inevitable and pervasive influence of power, and be able to produce 'theological honey' that can challenge and nurture a society in need of making sense of its precarious existence? OT scholars in South Africa must face up to the challenge and the responsibility of producing 'theological honey' - time will tell whether we were able to do so. ${ }^{3}$

What theological honey is there in discussing perpetrators within the context of South African whiteness? This celebratory essay to honour his scholarship and role as lecturer in Old Testament Studies wants to explore Bosman's question in looking at Manasseh as perpetrator. Although not explored here the context of this question is ominously present in current South African public discourse: the role of whiteness in the perpetration of racism. ${ }^{4}$ The critique of whiteness is very public, its effects no longer masked because of the decolonial project. ${ }^{5}$ The latter project requires from whiteness an acknowledgement of its role in perpetrating various kinds of oppression. Such recognition renders one vulnerable in its effects but in its provision of possibilities, it suggests a change in epistemology, something Bosman refers to in the above-mentioned article. ${ }^{6}$

This essay wishes to explore Manasseh's vulnerability in both narratives in terms of the current reader's own vulnerability. But before being able to start with that exploration, it is necessary to look at the theoretical basis for the argument of vulnerability as well as the presentation of Manasseh in 2 Kings 21:1-18 and 2 Chronicles 33:1-20.

\section{The Basis for Vulnerability}

My understanding of vulnerability is shaped by (a) a particular reading of Cain in Genesis 4 with the help of what Levinas called 'the ethical moment," (b) the notion of vulnerability as a negative state, and (c) Erinn Gilson's book The Ethics of Vulnerability. A Feminist Analysis of Social Life and Practice, which sees vulnerability as a human condition.

\section{Levinas' Ethical Moment}

On the basis of the $6^{\text {th }}$ commandment Levinas formulated his idea of the ethical moment as a face-to-face meeting between two human beings in which each one, reciprocally and metaphorically, become for the other someone without anything, someone without any relations or kinship, someone without family, parents, siblings, children, friends or colleagues. Each one confronts the other in his or her destituteness and proverbial nakedness. Both face each other, crying out not to be killed by the other. The face demands from the other a radical obligation to not destroy or violate the other.

The face, and more specifically, the eyes are central to the ethical moment. With reference to Cain in Genesis 4, Levinas argues as follows:

The face ... is inviolable; those eyes, which are absolutely without protection, the most naked part of the human body, none the less offer an absolute resistance to possession, an absolute resistance in which the temptation to murder is inscribed: the temptation of 
absolute negation... For in reality, murder is possible, but it is possible only when one has not looked the Other in the face. The impossibility of killing is not real, but moral. ${ }^{8}$

Abel's voice from his blood in the soil activates the ethical function in the story. Levinas utilises the vocal as well as the visual to call the self to account for the other. Abel's eye did not prevent his murder, but his voice persecutes Cain from beyond the grave as if it is the deity's eye following Cain. Ultimately, the destitution in the face of the other cries out for justice and designates responsibility. But Cain cannot see it, as his own face, or countenance, has fallen: "The fall of the face, in some sense, is the negation of the face, an event of psychological death which indeed leads to Cain's inability to face the other and recognise him, and issues, as though inevitably, in the latter's [Abel] murder." Cain and Abel's story is one of failure in an ethical sense, argues Ben-Naftali. ${ }^{10}$

From the interaction of two faces meeting each other, it follows that the one cannot do without the other. To be human is to be recognised as such by the other. It is reciprocal. James Perkinson takes it to its consequences:

To achieve a genuinely human dignity of spirit, each consciousness must risk itself to the point of becoming a threat to the other. It must face into the other's fierce gaze, give birth to desire and plunge into what lies beyond life, risk death and meet the other's (reciprocal) resistance with utmost struggle... To become a reality in-itself-for-itself, human 'being' must pass through the phase of serving negative notice to its other: "Here I stake life itself; I refuse to remain immediately, "naturally' within myself."

With the colonial and apartheid legacy, however, the gaze was never reciprocal. The black gaze only met indifference at best, negation at worst. ${ }^{12}$ Subsequently, a different black gaze developed through the anti-apartheid struggle - one with a particular black consciousness that would become a face of terror for whites. Whiteness was outed, in Perkinson's words: "[w]hite people were finally, briefly, made to look in the mirror of race and confront a gaze that looked back, but did not look alike." ${ }^{.13}$ It is a gaze that is no longer captive to the white gaze. To the contrary, it forces the gaze of the (white) other to become consciously aware of its own body as human; the black gaze becomes its pedagogue. ${ }^{14}$ The vulnerability of the black other needs to be recognised by the white gaze in order for whiteness itself to realise its own vulnerability. The imperative to come to consciousness of oneself as white is founded upon a "daring to look into black eyes and not deny the reflection," even when it proves to be embarrassing by having been found out by one's most frightening other. ${ }^{15}$

\section{Vulnerability as a Negative State}

Vulnerability reveals itself in the ethical moment created by the meeting of two faces, of two pairs of eyes looking at each other, reciprocally exclaiming, "Do not kill me!" Within a paradigm of subordination, at least one pair of eyes negates the other, exploiting the latter's vulnerability. It is in this context that the need for recognising the vulnerability of the other arises. Hence the need for Article 8 in the 2005 UNESCO Declaration on Bioethics and Human Rights. ${ }^{16}$ However, it is a vulnerability in negative terms according to which certain individuals and groups of people are in need of special protection - those who are exposed to the possibility of being misused or abused, physically or emotionally attacked or harmed. They are in need of special care or protection because of their age, disability or specific risk to be harmed or abused. However, this rather negative definition is shaped for the biological sciences. It cannot deal with justice in the same way social or cultural vulnerability can. ${ }^{17}$ 
Thinking of vulnerability in this way creates an association between vulnerability and affliction, suffering, harm, or injury. The South African $O E D$ defines vulnerability in this way. Understandably, no one wants to be in a position of such vulnerability. It is associated with weakness, powerlessness, and subsequent exploitation. Anyone will want to avoid such vulnerability, since it signals weakness and lack of mastery and control. Vulnerability does not equal well-being. It is something to overcome. ${ }^{18}$

The purveyors of vulnerability in bioethics acknowledge the limits of the definition. ${ }^{19}$ The UNESCO definition sees a vulnerable person as a failed autonomous subject in terms of a particular Western paradigm. What is not clear are the social, political, economic, and religious dimensions that also causes vulnerability. In other words, vulnerability is not merely a deficit of autonomy. Of particular concern is the production of vulnerability itself. ${ }^{20}$ Vulnerability as a deficit of autonomy assigns to the vulnerable inferiority, weakness and dependency. The antidote is capability, strength, autonomy, and well-being. In other words, vulnerability is not a human condition. It constitutes an abnormality that only someone strong - an admirable invulnerable saviour - can fix. Accordingly, since the vulnerable lacks agency to overcome vulnerability, the vulnerable needs to open up towards patronising attitudes of paternalism with subsequent affirmation of inequity and hierarchy. ${ }^{21}$ As a fixed negative state, vulnerability is stigmatising and oppressive. It symbolises powerlessness, which no one would want to acknowledge. Acknowledgement would be tantamount to a recognition of weakness and lack of control, that is, autonomy.

Understanding vulnerability as a negative position necessarily sets one on the road towards invulnerability. Erinn Gilson refers to an epistemology of ignorance that wilfully cultivates invulnerability as ignorance of vulnerability. This ignorance props up a subjectivity of a self-sufficient master subject that maintains itself as independent and invulnerable. ${ }^{22}$ To be confronted with vulnerability is deeply uncomfortable and uneasy; to ignore it aims to maintain a strong and competent masterful subjectivity. Gilson argues that invulnerability is constitutive of the master model of subjectivity with which Western science is practiced - it is constitutive of the cultural identity of those who occupy positions of privilege and who participate in domination by values such as detachment, selfcontainment, self-mastery, and control. ${ }^{23}$

The link between vulnerability and autonomy put on the table in the medical science in the nineties of the previous century was indicative for the development of the 2005 UNESCO Declaration on Bioethics and Human Rights. Ten Have, who was deeply involved in the construction of this declaration, later acknowledged that vulnerability is less the result of lack of respect for personal autonomy than the result of a lack of justice, equality and solidarity. ${ }^{24}$ In fact, Ten Have sees it as part of the 'inherently fragile' human condition in need of protection, yet creating an openness to the world because "[w]e cannot come into being, flourish and survive if our existence is not connected to the existence of others." 25

\section{Vulnerability as a Shared Human Condition}

The basic premise of a hermeneutic of vulnerability is that vulnerability is a basic human condition. It is not marginal but fundamental, unavoidable, and inherent to our being human - physically, corporeally, and socially. ${ }^{26}$ The negative and popular view of vulnerability associates vulnerability with harm, injury and weakness. However, vulnerability is not the harming itself, but only the susceptibility to harm or the ability to be wounded. ${ }^{27}$ Vulnerability makes harming possible. In other words, vulnerability is a potential condition that enables certain capacities. 
As a basic common human condition, vulnerability is shared between human beings. It is not a category set apart from those deemed invulnerable. ${ }^{28}$ Of course, ontological vulnerability is attributed to human beings, but not everybody may experience themselves as vulnerable. In contrast, vulnerability as experience is situational because of race, gender, class, sexuality, disability, nationality, etc. ${ }^{29}$ The problem is that as soon as it is designated as a property that pertains to certain groups of people rather than an experience or condition, vulnerability becomes viewed in a negative light.

As a shared common condition, vulnerability entails the exposure of our bodies to the gaze and touch of others whilst the bodies of others are similarly exposed to our scrutiny and physical contact. The shared and common nature creates a (political) community in which one has no choice but to participate, because one always stands in relation to others. ${ }^{30}$ The relation with other creates vulnerability, and because of it, violence. ${ }^{31}$

Our being exposed to others as well as our experiencing the exposure of the other to us are premised upon violence: the latter makes one aware of vulnerability. Violence shows how one is vulnerable in relation to the other in terms of being formed in violence and/or in terms of violence with which one conducts oneself.

Nonetheless, the link between vulnerability and violence leaves the impression of a reductively negative understanding of vulnerability as weakness, harm and injury. This kind of violence is a destructive violence dividing a community into victims and perpetrators. $^{32}$ In this instance vulnerability can only pertain to one party in a relationship vulnerable sufferers over-against invulnerable perpetrators. ${ }^{33}$ The latter can indeed be vulnerable, but when the norms that enable the recognition of vulnerability are regulated by dehumanising frameworks, the vulnerability of a perpetrator will be imperceptible and unrecognisable. ${ }^{34}$ A prisoner, for example, is not regarded as vulnerable, but dangerous, and thus does not deserve response when harmed in the prison system. The perpetrator is not seen as in need of protection. Vulnerability, understood in this way, ascribes to a dualist conception in terms of who merits and who does not merit vulnerability. It presumes a hierarchical and inequitable distribution of vulnerability that "generate[s] patronising, oppresssive, paternalistic and controlling, and stigmatising and exclusionary dispositions and treatments of others.",35

Over-against this reductively negative view of vulnerability, Erinn Gilson proposes a concept of epistemic vulnerability. ${ }^{36}$ Epistemic vulnerability can be summarised by the terms openness and affectivity. It is an openness to not knowing, to be wrong yet not refraining from interaction in which one's ideas, beliefs and feelings are put to the test. Epistemic vulnerability enables one to learn in a context where one is unknowing and foreign, a context where one is not in power. Openness to new ideas entails the dispelling of wilful ignorance and altering unconscious beliefs and habits that are ingrained into our bodies. It entails an openness to the ambivalence of our bodily and emotional responses, to enable knowledge to sink into our bodies. Openness to alter beliefs and habits also entails an openness to altering oneself as well as the concept one has of the self. In other words, the change that takes place, should affect what one does, how one thinks about and defines oneself. Gilson defines it as follows:

If epistemic vulnerability is defined by openness to changes in the self in light of coming to perceive what one does not know and has prevented oneself from knowing, then it entails a different perspective on change, permanence, history and the formation of the self. In allowing the self to change, one likewise allows change in what one knows, how one knows, and in relation to whom and what one knows. Thus, epistemic vulnerability entails rejecting the closure of the self that defines invulnerability. Instead, one begins to 
comprehend oneself as a being who has come into being and is continually evolving, one positions oneself as one who has been and will continue to be affected by others; one perceives oneself as vulnerable and conceives this vulnerability as the condition of one's knowledge since it is only by being affected by others that one knows and is. ${ }^{37}$

\section{Vulnerability and Oppression}

Levinas' ethical moment in which the naked face of the other plays a crucial role, creates vulnerability. It is then in terms of vulnerability that an ethical responsibility is called forth: "The Other, a stranger who shares my humanity, exacts from me a certain responsibility to respect his dignity once I am aware of our interconnectedness." 38 Vulnerability and ethical responsibility are fairly commonly constructed in different religions under the names of "agape or charity, neighbourly love, solidarity, visheshdharma, ren, karunā or compassion, and mercy or hesed." 39

From the discussion so far it is clear that vulnerability can be interpreted in two ways: a reductively negative understanding that sees it as weakness, harm and injury, in line with the common perception of vulnerability as expressed in dictionaries; and as a common condition of humanity that makes wounding possible. In this sense, vulnerability is a potential that requires an openness to affect and be affected, the ability to be harmed and experience loss, and the ability to transform oneself and change deep-seated habits.

It is with the latter understanding of vulnerability that I renew my proposal for a hermeneutic of vulnerability in order to take seriously that ethical obligation the naked face of the Other imposes on me. ${ }^{40}$ Such an obligation is especially imperative in the current South African post-apartheid context in which whiteness is forced to face the consequences of apartheid in particular and the entire population the aftershocks of colonialism in general. A hermeneutics of vulnerability enables one to unmask the privileged positions apartheid and colonialism have allocated to a certain group at the expense of other groups.

Recognising vulnerability is a helpful step in dismantling the after-effects of apartheid. However, from a position of privilege and sovereignty, a common reaction still seems to be one of disavowal and avoidance of vulnerability. ${ }^{41}$ In this context, vulnerability is seen as an impediment and limitation that needs to be repudiated and ignored; a quality one would rather project onto others. A failure to recognise vulnerability facilitates the flourishing of oppressive social, economic and political relations, or, conversely, to undo oppressive relations it is necessary to recognise vulnerability. ${ }^{42}$

In other words, an assured ignorance of vulnerability is cultivated in order to achieve a sense of invulnerability in terms of a self-sufficient sovereign subjectivity. Cultivated willfully or subconsciously, invulnerability produces and maintains ignorance. ${ }^{43}$ Willful ignorance of the after-effects of apartheid and the lingering residues of racialised thinking enables the persistence of white privilege and racism. It is more than not caring to know. Willful ignorance is continuously produced in the choices people make and their actions. ${ }^{44}$ Knowledge of vulnerability produce extreme discomfort and unease, needing to be repudiated in order for the sovereign self-sufficient master subject to remain in a position of power and privilege.

Moreover, vulnerability is rather objectionable when the power remains asymmetrical with the privileged not only in possession of what the vulnerable needs, but also in control of the access to that which the vulnerable needs. ${ }^{45}$ Thus, the vulnerable is forced to seek the help of the self-sufficient invulnerable as the saviour. 


\section{Manasseh in 2 King 21:1-18 and 2 Chronicles 33: 1-20}

\section{Manasseh's Villainy in both Narratives}

In the story of Manasseh in 2 Kings 21:1-18 the kingdom of Judah is rendered extremely vulnerable because of the actions of Manasseh as king. Manasseh receives the blame for the destruction of Jerusalem by the Babylonians. Both 2 Kings 21:1-8 and 2 Chronicles 33:1-8 participate in the vilification of Manasseh. The sins attributed to Manasseh indicate key aspects of Deuteronomistic law. ${ }^{46}$

2 Kings 21:2/2 Chronicles 33:2: The deity regarded Manasseh as evil since he followed the abominable practices of the nations that YHWH drove out before Israel

\section{Kings 21:3, 7/2 Chronicles 33:3:} Manasseh is accused of returning the high places and erecting high sacred poles for Asherah.

2 Kings 21:3, 5/2 Chronicles 33:3, 5, 7: Manasseh erected altars for Baal and the host of heaven in the two courts of the temple.

2 Kings 21:6 2 Chronicles 33:6: Manasseh is accused of sacrificing by fire his children for Moloch and practicing divination by visiting mediums and wizards and practising soothsaying and augury.

2 Kings 21:16 (no parallel in 2 Chronicles 33): Manasseh shed so much innocent blood that it filled Jerusalem.
Deut 12:29-30: Israel is warned against the abominable practices of the nations they are about to drive out of Canaan and ordered not to inquire about worshipping them in order to imitate these abhorrent practices (see Deut 18:9).

Deut 12:2-4: The people are admonished to destroy all the high places in the hills and mountains as well as under the trees. Deut. 16:21 prohibits the planting of any tree with the aim of making it a sacred pole for Ashera.

Deut. 17:3: Any man or woman found to have worshipped other gods, such as sun, moon or host of heaven, will be stoned to death.

Deut 18:9-14 polemicises the abhorrent practices of the nations Israel drove out of Canaan: passing children through fire, practices of divination, soothsaying, augury, sorcery, consulting ghosts, and seeking oracles from the dead.

Deut 19:10 prohibits the shedding of innocent blood on caution of bloodguilt.

Both the Deuternomist and the Chronicler provide negative portrayals of Manasseh that can be labelled with the term 'blackballing. ${ }^{47}$ In Kings Manasseh is not regarded among the successful kings of Judah. ${ }^{48} \mathrm{He}$ is marked as Judah's Ahab in 2 Kings 21:3 for making a sacred pole and an altar for Baal similar to Ahab. Ahab was the epitome of depravity in the Northern Kingdom. Manasseh is not the only king in Judah committing various idolatrous evils, but his shedding of innocent blood (2 Kings 21:16) placed him at the pinnacle of those who committed cult crimes with regard to the laws laid down in the Deuteronomistic history. ${ }^{49}$ 
Manasseh's Wickedness in 2 Kings 21:1-18

Judah's eventual exile is blamed on Manasseh's wickedness and transgression of Deuteronomistic law. He is constructed as a scapegoat and villain in order to provide a comforting explanation for an audience struggling with exile and catastrophe ${ }^{50}$ Yet Manasseh is distanced from Judah in being closely associated with aspects of the Northern Kingdom. The latter was destroyed because of their following of the cults of the foreign nations their extreme foreignness remaining a focus in the Manasseh narrative. ${ }^{51}$ Manasseh is associated with these "abominable practices of the nations that YHWH drove out when they entered the Promised Land" (2 Kings 21:2). In fact, he was even worse than these nations in that he saw to it that Judah worshipped these idols (v. 11).

His following of the foreign cults strengthens the comparison in v. 3 with king Ahab and the analogy with Jerobeam, the foremost villainous king of the Northern Kingdom. Manasseh and the latter are compared to the Amorites (2 Kings 21:10 and 1 Kings 21:26). The reference to Ahab depicts Manasseh in ways even worse than Ahab himself. ${ }^{52}$ Manasseh parallels Jeroboam who is also accused of causing the people to sin (1 Kings 14:16). Manasseh's wickedness has the same consequences Jerobeam's evil initially had for Israel. It is as if these three kings are in competition of being portrayed as the most evil: "Manasseh appears to have been depicted as akin to the worst monarchs, especially Israelite ones, and as the opposite of the best kings.. ${ }^{53}$ Nonetheless, his wickedness completely outweighs Josiah's piety and cultic reforms (2 Kings 23:4-24). ${ }^{54}$ In fact, Manasseh's wickedness had an impact on Josiah's role in Deuteronomistic history: although apparently repairing the damage Manasseh did, his cultic reforms failed to thwart the destruction of the temple and Jerusalem, that resulted into the exile. "Manasseh's sin has doomed the reform to futility from the start." 55

Not only is Manasseh linked to the Northern Kingdom by Ahab (2 Kings 21:3) and Jerobeam (2 Kings 21:11), his name is also of Northern Kingdom origin (1 Kings 3:13). ${ }^{56}$ It seems the name's presence in the biblical texts functions in terms of an anti-Manasseh polemic: "His vilification in Kings is prompted by his name: in sharing a name associated with the Northern Kingdom, Manasseh is singled out as a religious deviant in the eyes of the Kings Writer." ${ }^{, 57}$ In other words, it is as if the narrative in listing all Manasseh's crimes and linking Manasseh to the Northern Kingdom, asks the reader what they expect from such a man. Nevertheless, two things happen in the process: a king whose reign was 55 years long, and in terms of Deuteronomistic theology a successful king, is completely vilified and attributed the exile of a kingdom, whilst the inhabitants of the kingdom abscond their own responsibility.

\section{Manasseh's Wickedness and Vulnerability in 2 Chronicles 33:1-20}

2 Chronicles 33:1-9 more or less replicates 2 Kings 21:1-9, except that Ahab is not mentioned in the Chronicles version. Verses 10-17 tell the story quite differently from the Kings' version, perhaps with more of a recitation of generic impieties and without reference to Manasseh's slaughter of innocent people in Jerusalem. ${ }^{58}$ Here Manasseh is said to have failed to listen to YHWH and the latter sent the Assyrians to humiliate him publicly in taking Manasseh captive in manacles and in binding him in fetters in order to take him to Babylon. ${ }^{59}$ In Babylon Manasseh experienced conversion ${ }^{60}$ and he was sent back to Jerusalem where he induced religious reforms and initiated large building projects, as evidence that his reign was successful and long. The building of the wall, alluding to Nehemiah's own wall building project, suggests a presentation of Jerusalem as the central 
administrative location for the province - Jerusalem is mentioned five times in the Manasseh narrative. ${ }^{61}$

How does one explain the repentance of Manasseh in the Chronicles narrative? His repentance appears to be indicative of vulnerability and subsequent change in thinking and behaviour. Readers offered various explanations. One suggested that his long reign was incompatible with the image of a scapegoat and it became theologically necessary to have him end his reign successfully. ${ }^{62}$ Another argued that the Chronicler had a choice of either explaining the long reign or change the length of the reign. He chose the former in linking the reign to Manasseh's repentance. ${ }^{63}$ However, for what did Manasseh repent? The Deuteronomistic history suggested cultic abominations, a problem even in the Persian Period. Manasseh's Ba'als, Asherah's and host of heavens became those deities that were not the God of Abraham, Isaac, and Jacob: in the Diaspora the Jews were confronted with worshipping foreign deities and in Yehud, those who settled there under the migration policies of the Empire brought with them their own cult. Manasseh symbolised those Jews who accepted these foreign cults. ${ }^{64}$

Whereas the Kingdom of Judah experienced the consequences of Manasseh's apostasy a few generations later, retribution is immediate and personal in the book of Chronicles. Retribution is constructed in terms of the Assyrian Empire striking Judah. Theologically, Assyria became the rod of Yahweh's anger and the club of his fury (Is. 10:5). ${ }^{65}$ Manasseh's capture is public and meant to be humiliating, although Japhet thinks that his capture is "a relatively mild reaction and quite disproportionate to the gravity of his evil when compared to someone like Jehoram's bowel disease (2 Chronicles 21:18)."66

While in captivity Manasseh repents and prays to YHWH, who hears his pleas and forgives him by sending him back to Jerusalem (2 Chronicles 33:13). The appropriate response to his vulnerability is humility and prayer: Manasseh humbles himself before the deity and prays. The deity, in turn, in receiving his prayer and hearing his plea, restores him. Handy argues that the trope of repentance before a merciful deity stands central to Persian and Hellenistic literature and strands of the Jewish tradition can be noticed within the rabbinic tradition and the early Christian tradition. ${ }^{67}$ The prayer of repentance seemed to be of considerable importance. The Chronicler refers to it twice whereas in the Hasmonean period an apocryphal text was produced to fill in the contents of Manasseh's prayer. ${ }^{68}$ The prayer presents a Manasseh devoid of any evil, "a penitent and pious Manasseh," 69 yet somehow in the collective archive Manasseh failed to shed evidence of total wickedness.

Manasseh backs his repentance with a building project, a military strategy, and spiritual renewal. He builds a wall around Jerusalem and staffs the fortified cities with military commanders. Both projects allude to a strengthening of the power to resist. ${ }^{70}$ On religious level, he negates the cultic changes he brought about earlier except the high places. Moreover, in Chronicles no reference is made to child sacrifice, witchery, soothsaying or augury. It is as if something needed to be left for Josiah to do in Chronicles! ${ }^{71}$ Nonetheless, his reforms encapsulates the reforms of Josiah in Kings and the reader is left with an image of a monotheistic temple of $\mathrm{YHWH}$ with the high places also consecrated to the one single deity called $\mathrm{YHWH}^{72}$

\section{Two Traditions of Manasseh's Story}

It is clear that the story of Manasseh in Kings as well as Chronicles presents the reader with two traditions that developed consecutively and provided an impetus within the history of reception of Manasseh to two different readings. Handy summarises it well: 
During the period of Persian and Hellenistic rule there were two diametrically opposed trajectories regarding Manasseh that begin in the Persian period and carried on into early Judaism and Christianity. One leads straight from the book of Kings, intensifying the wickedness of Manasseh until he is presented as the tool of Satan, if not the embodiment of evil itself. In this trajectory Manasseh exemplifies the danger of Judeans/Jews who go after foreign cultures and harm Jewish practice. The other trajectory builds on the Chronicler's addition of Manasseh's prayer and repentance. Here Manasseh becomes the very embodiment of the penitent, producing a vision not only of a converted king but also of an all-merciful deity who provides a way to make amends for evil behaviour. Both extreme views of Manasseh are elaborations of the memory first encoded in Kings. The wonderful, temple-restoring, good king Manasseh developed in Yehud under Persian imperial rule. The Manasseh of irredeemable evil, incorporating the entire notion of Satan as the embodiment of evil, seems, as a working hypothesis, to have originated during the Hasmonean wars and rule. Remembering Manasseh as having abandoned the true faith, cult, and people of Israel, the authors could then equate those of their day who they felt followed in his footsteps with this national exemplar of wickedness. ${ }^{73}$

There is a strong tradition of regarding Manasseh in a negative light. ${ }^{74}$ In I Enoch Manasseh is compared to the blind straying bellwether who abandoned his flock of sheep to beasts of prey. In the Martyrdom of Isaiah (Chapter 5) Manasseh becomes demonic by his participation in sawing Isaiah into two. In 2 Baruch Manasseh is associated with apocalyptic imagery of destruction.

The portrayal of Manasseh in Rabbinical literature is quite ambivalent. The Talmud singles out Jerobeam, Ahab and Manasseh as those kings whose evilness caused them to forfeit their share in the world to come. ${ }^{75}$ But Rabbi Johanan (b. Sanh. 103a) argues that anyone who accepts this line of thought, weakens the power of repentance. The Talmud introduced Manasseh as a Torah-scholar who interpreted Leviticus in 35 different ways. ${ }^{76}$ In $b$. San $102 b$ he is not allowed to be judged since Yahweh already judged him. The Assyrian records portray Manasseh positively as a loyal vassal (Prism B and Prism C). ${ }^{77}$

In line with his association with the Northern Kingdom, the negative interpretation of his name received further impetus in the interpretative history. His name became suggestive of forgetfulness: he forgot God and his father Hezekiah. In fact, he is described as poking fun at his pious father when he was brought to the synagogue in his youth. He is also said to have violated his sister. His role as scapegoat is enhanced by incest and even parricide, such as the killing of his grandfather Isaiah. ${ }^{78}$ Idolatry, incest, shedding of blood and release of land indicates the causes for the exile. In the Kings version, Manasseh is linked to two of the four and in the post-biblical literature, three of the four seem to play a role. ${ }^{79}$

In the Pseudepigrapha he is depicted as being under the influence of Satan who led him to be the cause of Jerusalem's apostasy. Nevertheless, he is thought here as in the Talmud to have been a great scholar of the Torah despite his ridicule of it. The greater the scholar, the greater the evil inclination, the rabbis argued! His repentance reported in Chronicles did not go unnoticed in some rabbinical writings. His repentance redeemed him from losing out on his share of the world to come. ${ }^{80}$ Josephus, whose Antiquities was intended for nonJews, looks at Manasseh's transgressions as an internal affair and does not link it to the pagan religions surrounding Judah at that stage. He regards these transgressions as lawlessness that eventually brought down the Kingdom of Judah. In addition, he credits the origin of such lawlessness to Jerobeam. ${ }^{81}$

One scholar made an important observation regarding the scholarly interest in Manasseh: most authors usually side with the biblical heroes, like David, Solomon, Hezekiah, or Josiah. Villains, such as Manasseh, do not attract a lot of interest. ${ }^{82}$ When he 
does, scholarship seems to add to his vilification. For example, he is blamed for the introduction of foreign cults (despite evidence that the cult in those days differed very little from surrounding cultures or that his worshipping constituted a syncretistic cult enhanced by Assyrian beliefs). He is sometimes even accused of cult crimes not found in the biblical text. In his deviation, a personal and intentional villainy is assumed in his rejection of his father's reforms. ${ }^{83}$ One contextual study suggests an analogy between the two kinds of presentation of Manasseh and what is happening in an African context. ${ }^{84}$ The Assyrian praise for Manasseh, for example, is echoed by Western praise for African leadership that promotes and protects Western economic interests, whilst leadership that questions and problematises such approaches is portrayed as bad leadership in the eyes of the West.

\section{Vulnerabilty}

Starting with Levinas' ethical moment and the face-to-face dialectic with the other, reading the story of Manasseh in both Kings and Chronicles leads one to realise that the reader never really sees the face of Manasseh. He is very much a cardboard character because the narrative is manipulated to achieve other ends.

In 2 Kings 21 Manasseh's reign is long (and apparently successful if one compares it with that of Solomon). He does not suffer the consequences of his wrongdoing. The people of Jerusalem suffer. Subsequently, one tends to see vulnerability in a negative light: infliction of harm and punishment upon Jerusalem.

In 2 Chronicles 33, Manasseh is the one who suffers. On a different level, Manasseh as king represents autonomy, i.e. invulnerability. Yet one wonders whether his openness to other ways of worshipping does not constitute vulnerability as potential on his side, with the deity as the invulnerable opposite other. In his story, this openness tends to be harmful to the deity, who lashes out, rendering the king vulnerable. The more historical question one would ask is whether Manasseh's behaviour as king and his openness to other forms of religions were not valid for his time when YHWH was still the chief deity and the other deities part of the pantheon.

It is clear that the story in Kings searches for an explanation for the destruction of Jerusalem and the exile of Judah. It finds reason in the deeds of one person, Manasseh. ${ }^{85}$ However, in terms of the depiction of the kings of the Northern Kingdom, the actions of the whole kingdom resulted in divine destruction of the entire kingdom. ${ }^{86}$ In Judah's case, it is the misdeeds of a single king, Manasseh (who misleads Judah), which constitutes the cause for the fall of Jerusalem and the destruction of the temple. A particular problem arises: the divine promise of the Davidic House's eternal presence on the throne is nullified by the deeds of a single king: "Nevertheless, the question of the Deity's culpability in reneging on the promise to the house of David and in holding the entire nation responsible for the action of one man remains." 87

Römer is of the opinion that Manasseh was a loyal vassal and it was quite possible that he merely reinforced the cultic symbols to relate with Assyrian culture and politics. ${ }^{88}$ Buchner suggests that Manasseh steered a safe course between placating his Assyrian masters on the one hand and serving the religious needs of his population on the other, by maintaining the YHWH cult as the official cult, but resuscitating within it bolder expressions of folk religion, which included veneration of the goddess and now also Assyrian astral deities, who were visibly portrayed as part of YHWH court. ${ }^{89}$

Another possibility is that the catastrophic situation that saw the demise of the monarchy and the destruction of the temple in Jerusalem is parallel to the defeat of YHWH as national deity or him actively abandoning his elected favourite, Israel. Within Judah itself, 

or rather, within the exiled powerful elite, (Römer refers to them as 'mandarin, ${ }^{90}$ ), the scribes and administrators, sought to explain the loss of power and exile in terms of a deity who provoked the Babylonian invasion to punish his elected people:

L'exil et la déportation sont le theme global de cette histoire qui relie les diverses traditions et périods pour aboutir à la fin de la monarchie, la destruction de Jérusalem et la perte du pays, évènements qui, selon les deutéronomistes, résultes de la colère de YHWH contre son people et ses chefs. Juda et Jérusalem ne peuvent échapper à l'attaque babylonienne parce que c'est YHWH lui-même qui a envoyé cette armée pour annihiler Juda et Jérusalem. ${ }^{91}$

To Römer it is not a question of Babylonian deities conquering the national god of Judah, but a question of divine wrath as agent in afflicting Judah. And if YHWH used the Babylonian deities in this way, it means he controls them too, preparing the way for monotheism to be finalised within the Deuteronomistic history ${ }^{92}$ and Deuteronomy itself (Deut 4:39):

C'est une manière remarquable de maintenir l'ancienne idée de YHWH comme dieu national ou tutélaire, tout en affirmant qu'il est le seul vrai dieu. ${ }^{93}$

The composite nature of the biblical text in overlaying traditions on top of one another presents readers with two contradictory and sometimes mutually exclusive portrayals of the deity YHWH: YHWH as the only and universal deity and YHWH as one amongst many, albeit the head of the divine council or of the other deities. ${ }^{94}$ These discordant incongruous views about YHWH are deliberately constructed:

A nascent, monotheistic community in the Persian province of Beyond the River would have had a vested interest in both approaches - one more subtle and the other more direct, to critique old orthodoxy and orthopraxy of the monarchic era that still existed in Yehud. They wished to rebuff the understanding of Yahweh as the head of a pantheon, replacing it with a monotheistic Yahwism that allowed for angelic, messenger-type beings. 95

The new view would have entailed economic benefits to the priestly scribal class in pushing for a new ideology, yet not alienating those who pay taxes and make voluntary sacrifices in the temple. Yet, the new view made it clear that the ways of the past, worshipping YHWH as part of a pantheon, led to the catastrophe of the exile and the destruction of the temple and Jerusalem. The Exile becomes the result of the religiosity and behaviour of the past. ${ }^{96}$ If this is true, the context of the authors of these texts was still very precarious because of the corrupt ways of the past:

The [new form of Yahwism] was essentially used to state more openly and directly that the old position, though still around, where Yahweh was the head of a pantheon, was a bad one. Look what happened - Yahweh allowed us and our ancestors to suffer and be subjugated and taken into captivity because of our apostasy in worshipping him incorrectly. ${ }^{97}$

An unintended consequence of the development into monotheism is that the deity is made invulnerable and defended against other deities. Noncompliance by human beings makes the latter extremely vulnerable and the object of harm and injury by the deity.

By the time Kings wrote the story, monotheism started to set in and the story was constructed in that way, resulting in the depiction of Manasseh as idolatrous. Philip Davies draws a link between the political development of the monarchy from a national institution to an imperial one and the religious development towards monotheism in the Persian Period. $^{98}$ Following his remarks on the development of monotheism, ${ }^{99}$ it is clear that autonomy parallelled invulnerability. The monarchy emerged as an autonomous locus of 
power with the ability to impose taxes, engage in war and require personal loyalty, which encouraged a parallel religious development with a centralised cult. The kingship on earth reflected the divine kingship in heaven. The monarch as well as the deity became invulnerable, i.e. any effort to render them vulnerable was met with negative sanction. Both lived in a designated area with designated personnel to serve them. The emergence of empire allowed for the construction of a dynastic deity that overshadowed the local or nationalistic deities of the vassal-kings and their states, sometimes causing a tension in loyalty towards either of the deities. Monarchic theism became imperial theism. In Chronicles, in the last verses of the book, the deity becomes imperial in its support for the new imperial ruler.

Does monotheism in the story not create a reductively negative view of vulnerability? In terms of invulnerability, Gilson talks of a self-sufficient or autonomous master subject who remains independent and invulnerable. Gilson links such a model to a particular epistemology that has become constitutive to the practice of science as well as top positions of privilege and control in the West. In other words, in order to stay invulnerable, vulnerability has to be ignored. It is a god-like position and currently associated with whiteness and white privilege. In Manasseh's story, the deity is thought to be invulnerable and worshipping other deities harms that invulnerability. Such harm has consequences, according to the Kings story within a Deuteronomistic framework. The divine response is one of violence.

In the Kings narrative, Manasseh can be seen imitating this violence. He is said to have shed so much blood that it filled Jerusalem from end to end ( 2 Kings 21:16). He caused harm and rendered his people vulnerable. Yet, these very vulnerable people later pay the price for Manasseh's act of invulnerability as his punishment - Manasseh renders the deity vulnerable in his openness towards others and because of his position as invulnerable king, his subjects are rendered vulnerable a few years after he has died. In Kings the subject people do not merit vulnerability. There seems to be an inequitable distribution of vulnerability generated by a power structure that was patronising and oppressive. The Kings version of Manasseh's story presents the reader with a cause and effect scheme: actions have consequences. Vulnerability is largely perceived negatively. 2 Chronicles 33 repeats the cause and effect scheme, but it adds affect: Manasseh repents and become vulnerable. This vulnerability allows him to be open to change, albeit then a change forced by an invulnerable monotheistic god. Although the deity tolerated Manasseh, the exile and the destruction of the temple did not change. It still happened, though for other reasons in Chronicles.

\section{Conclusion}

Perpetrators are not always dealt with kindly in the Hebrew Bible/Old Testament, but in contrast to the negative portrayal in 2 Kings 21:1-18, Manasseh receives a better hearing in 2 Chronicles 33:1-20. There are obvious historical reasons in the respective worlds of text production of these different portrayals, but playing the role of perpetrator is never easy. For this reason, Manasseh's role in Chronicles is somewhat symbolical for the kind of perpetratorhood I need to deal with as reader in the current South African context. The ethical moment refers to the gaze of the eyes. In the Kings narrative, Manasseh does not look anyone in the eye. He is simply depicted in all his evilness. Then, he is not a rounded character in that representation. On a different level, I could ascribe a certain vulnerability to him in that he allows for the veneration of other deities. In terms of the power configuration, he was wise to do it as his long reign indicates. In Chronicles, he comes to 

consciousness of his wrongdoing and becomes vulnerable in captivity. Vulnerability allows him to return and change the epistemology.

A central focus in both stories is the role played out by the deity and Manasseh's response to that role. The stories suggest royal subordination to divine power. In Kings, the conflict is between Yahweh and the king, a monotheistic deity and royal power that were in need of being curtailed. In Chronicles, the story is about the subordinate king recognising the power of the single deity.

In both these cases vulnerability is characterised negatively as harm, injury, and death (or murder). It is a vulnerability one would want to overcome. The issue of autonomy of the king as well as the deity exacerbates vulnerability as harm or injury. Both narratives want the king to be subordinate to divine power, but it fails to happen. The story thus needed a saviour to make it happen. In Chronicles, that saviour is explicitly YHWH who sends the Assyrian army to take Manasseh captive in order to render him vulnerable. In the Kings narrative, Manasseh seems to uphold his invulnerability, only to render his subjects utterly vulnerable a few years on in the face of renewed captivity. Ironically, vulnerability is effected by an invulnerable monotheistic deity.

Because Manasseh never repented in the Kings narrative, one can surmise he remained ignorant of vulnerability. In Chronicles, Manasseh is confronted with it directly when he is turned fragile in captivity. Moreover, his body is violated with manacles and fetters, a public humiliation. Manasseh became physically vulnerable, a position from which he repented and which brought about changes. He experienced vulnerability in a particular situation: captivity, or prison where his autonomy became severely curtailed. As prisoner Manasseh seems to have experienced an epistemic vulnerability, especially an openness to being wrong. It is this kind of vulnerability that enables me from a position of whiteness to negotiate the apartheid past in a post-apartheid world.

\section{BIBLIOGRAPHY}

Anderson, James. "Creating Dialectical Tensions: Religious Developments in PersianPeriod Yehud Reflected in Biblical Texts." Pages 10-23 in Religion in the Acahaemenid Persian Empire. Emerging Judaism and Trends. Orientalische Religionen in der Antike 17. Edited by Diana Edelman, Anne Fitzpatrick-McKinley and Phillipe Guillaume. Tübingen: Mohr Siebeck, 2016.

Areff, Ahmed. "Listen: Whites Took Nothing from No One - Pastor André Olivier." News24.com, June 28, 2916. http://www.news24.com/SouthAfrica/News/listenwhites-took-nothing-from-no-one-pastor-andre-olivier-20160628.

Becker, Joachim. 2 Chronik. Vol. 20. Die neue Echter Bibel. Kommentar zum Alten Testament mit der Einheitsübersetzung. Würzburg: Echter, 1988.

Ben-Naftali, Michal. “Abel's Look. Levinas Reads Cain.” Pages 133-47 in Levinas Faces Biblical Figures. Edited by Yael Lin New York: Lexington Books, 2014.

Bosman, Hendrik L. "Ants, Spiders or Bees . . . and Ticks? A Typology of Old Testament Scholarship in South Africa since 1994 within its African Context," Old Testament Essays 28, no. 3 (2015):636-54. doi:http://dx.doi.org/10.17159/2312$3621 / 2015 / \mathrm{v} 28 \mathrm{n} 5 \mathrm{a} 5$.

Buchner, Dirk. "Boshet in Jeremiah 3:24: Disenfranchisement and the Role of the Goddess in Seventh-Century Judah.” Journal of Theological Studies 59, no. 2 (2008):478-99. 
Davies, Philip R. "Monotheism, Empire, and the Cult(s) of Yehud in the Persian Period." Pages 24-56 in Religion in the Achaemenid Persian Empire. Emerging Judaism and Trends. Orientalische Religionen in Der Antike 17. Edited by Diana Edelman, Anne Fitzpatrick-McKinley and Phillipe Guillaume. Tübingen: Mohr Siebeck, 2016.

Feldman, Louis H. “Josephus' Portrait of Manasseh.” Journal for the Study of the Pseudepigrapha 9 (1991):3-20.

Gilson, Erinn. The Ethics of Vulnerability. A Feminist Analysis of Social Life and Practice. Routledge Studies in Ethics and Moral Theory 26. London: Routledge, 2016.

Halpern, Baruch. "Why Manasseh Is Blamed for the Babylonian Exile. The Evolution of a Biblical Tradition." Vetus Testamentum XLVIII, no. 4 (1998):473-514.

Handy, Lowel K. "Rehabilitating Manasseh: Remembering King Manasseh in the Persian and Hellenistic Periods. Social Memory and Imagination." Pages 221-35 in Remembering Biblical Figures in the Late Persian \& Early Hellenistic Periods. Edited by Diana Edelman and Ehud Ben Zvi. London: Oxford University Press, 2013.

Heyd, David. "Jewish Perspective on Vulnerable Groups: Women and Children.” Pages 203-14 in Religious Perspectives on Human Vulnerability in Bioethics. Advancing Global Ethics, Vol. 2. Edited by Joseph Tham, Alberto Garcia, and Gonzalo Miranda. Dordrecht: Springer, 2014.

Japhet, Sara. I \& II Chronicles, a Commentary. Old Testament Library. London: SCM Press, 1993.

Kelly, Brian. "Manasseh in the Books of Kings and Chronicles (2 Kings 21:1-18; 2 Chron 33;1-20)." Pages 131-46 in Windows into Old Testament History. Evidence, Argument, and the Crisis of "Biblical Israel." Edited by V. Philips Long, David W Baker, and Gordon J. Wenham. Grand Rapids: Eerdmans, 2002.

Kritzinger, Klippies (J.N.J.). "Response to Pastor André Olivier of Rivers Chruch, Sandton.” Ahmed Kathrada Foundation, July 1, 2016. http://www.kathradafoundation.org/tags/klippies-kritzinger.

Lasine, Stuart. "Manasseh as Villain and Scapegoat." Pages 163-83 in The New Literary Criticism and the Hebrew Bible. Edited by Cheryl Exum and David J.A. Clines. Journal for the Study of the Old Testament Supplement Series 143. Sheffield: Sheffield Academic Press, 1993.

Levinas, Emmmanuel. Difficult Freedom. Essays on Judaism. Translated by Sean Hand. Baltimore: Johns Hopkins University Press, 1990.

Liss, Hanna. "“The Sins of the Prophets:' Biblical Characters through Rabbinic Lenses." Lexington Theological Quarterly 37, no. 4 (2002):197-213.

Morrow, William S. "Were There Neo-Assyrian Influences in Manasseh's Temple? Comparative Evidence from Tel-Miqne/Ekron." The Catholic Biblical Quarterly 75 (2013):53-73.

Myers, Jacob M. II Chronicles. Vol. 13. The Anchor Bible. New York: Doubleday, 1965. Nodet, Etienne. "Prières de Manassé (2 Chronicles 33, 1*; TSK 1.144*; 4Q381." Revue Bibliques 117, no. 3 (2010):345-60.

Ohm, Andrew T. "Manasseh and the Punishment Narrative." Tyndale Bulletin 61, no. 2 (2010):237-54.

Opperman Lewis, Helene. Apartheid, Britian's Bastard Child. Wandsbeck: Reach Publishers, 2016. 
Page, Hugh. "Prayer of Manasseh." Pages 316-18 in The Africana Bible. Reading Israel's

Scriptures from Africa and the African Diaspora. Edited by Hugh Page.

Minneapolis: Fortress Press, 2010.

Perkinson, James W. White Theology. Outing Supremacy in Modernity. New York:

Palgrave, 2004.

Römer, Thomas. L'invention de Dieu. Les Livres du Nouveau Monde. Paris: Seuil, 2014.

Smith, Morton. "The Veracity of Ezekiel, the Sins of Manasseh, and Jeremiah 44:18." Zeitschrift für die Alttestamentliche Wissenschaft 87, no. 1 (1975):11-16.

Snyman, Gerrie F. “A Hermeneutic of Vulnerability: Redeeming Cain?” Stellenbosch

Theological Journal 1, no. 1 (2015):633-65.

doi:http://dx.doi.org/10.17570/stj.2015.v1n2.a30.

Snyman, Gerrie F. "Cain and Vulnerability: The Reception of Cain in Genesis Rabbah 22 and Targum Onkelos, Targum Neofiti and Targum Pseudo-Jonathan.” Old

Testament Essays 29, no. 3 (2016):601-32. doi:http://dx.doi.org/10.17159/23123621/2016/v29n3a14.

Snyman, Gerrie F. "Empire and a Hermeneutics of Vulnerability. XXXVII - Supplement, December 2011:1-20.” Studia Historiae Ecclesiasticae XXXVII, no. Supplement (2011):1-20.

Snyman, Gerrie F. "Obadiah and a Hermeneutic of Vulnerability." Pages 45-63 in Obadiah. Readings: A New Biblical Commentary. Edited by Bob Becking. Sheffield: Sheffield Phoenix, 2016.

Snyman, Gerrie F. "Responding to the Decolonial Turn: Epistemic Vulnerability." Missionalia 43, no. 3 (2015):266-91. doi:http://dx.doi.org/10.7832/43-3-77.

Stavrakopoulou, Francesca. "The Blackballing of Manasseh.” Pages 248-63 in Good Kings and Bad Kings. The Kingdom of Judah in the Seventh Century BCE. Edited by Lester Grabbe. T\&T Clark Biblical Studies. London: T\&T Clark, 2007.

Sweeney, Marvin A. "King Manasseh of Judah and the Problem of Theodicy in the Deuteronomistic History." Pages 264-78 in Good Kings and Bad Kings. The Kingdom of Judah in the Seventh Century BCE. Edited by Lester Grabbe. T\&T Clark Biblical Studies. London: T\&T Clark, 2007.

Ten Have, Henk. "Vulnerability as the Antidote to Neoliberalism in Bioethics / Vulnerabilidad Como Antídoto Al Neoliberalismo En Bioética." Revista Redbioética/UNESCO 5, no. 1 (2014):87-92.

Tham, Joseph. "Lessons Learned." Pages 215-24 in Religious Perspectives on Human Vulnerability in Bioethics. Advancing Global Ethics, Vol. 2. Edited by Joseph Tham, Alberto Garcia, and Gonzalo Miranda. Dordrecht: Springer, 2014.

Tham, Joseph. "The Principle of Vulnerability: Meeting Ground of Six Religions.” Pages 1-8 in Religious Perspectives on Human Vulnerability in Bioethics. Advancing Global Ethics, Vol. 2. Edited by Joseph Tham, Alberto Garcia, and Gonzalo Miranda. Dordrecht: Springer, 2014. Doi: 10.1007/978-94-017-8736-9_19.

Tuana, Nancy. “The Speculum of Ignorance: The Women's Health Movement and Epistemologies of Ignorance." Hypatia 21, no. 3 (2006):1-19.

Van Keulen, Percy S.F. "Manasseh through the Eyes of the Deuteronomists. The Manasseh Account (2 Kings 21:1-18) and the Final Chapters of the Deuteronomistic History." PhD, Leiden, 1995. 
Vengeyi, Obvious. "King Manasseh of Judah: A Paradigm for Understanding what lies behind Good/Bad African Leadership Dichotomy." Review of Human Factor Studies 20, no. 1 (2014):99-130.

\section{Endnotes}

1 David Heyd, "Jewish Perspective on Vulnerable Groups: Women and Children," in Religious Perspectives on Human Vulnerability in Bioethics. Advancing Global Ethics, Vol. 2, ed. Joseph Tham, Alberto Garcia and Gonzalo Miranda (Dordrecht: Springer, 2014), 203.

2 Tham, "Lessons Learned," 221.

3 Bosman, Hendrik L. "Ants, Spiders or Bees . . . and Ticks? A Typology of Old Testament Scholarship in South Africa since 1994 within its African Context." Old Testament Essays 28, no. 3 (2015):652. doi: http://dx.doi.org/10.17159/2312-3621/2015/v28n5a5.

4 See especially Gerrie F. Snyman, “A Hermeneutic of Vulnerability: Redeeming Cain?” Stellenbosch Theological Journal 1, no. 1 (2015b):633-65. doi: http://dx.doi.org/10.17570/stj.2015.v1n2.a30.

5 See Gerrie F. Snyman, "Responding to the Decolonial Turn: Epistemic Vulnerability." Missionalia 43, no. 3 (2015a):266-91. doi: http://dx.doi.org/10.7832/43-3-77.

6 Bosman, "Ants, Spiders or Bees . . . and Ticks?" 643.

7 See, Snyman “A Hermeneutic of Vulnerability: Redeeming Cain?” 633-65, see also Gerrie F. Snyman, "Cain and Vulnerability: The Reception of Cain in Genesis Rabbah 22 and Targum Onkelos, Targum Neofiti and Targum Pseudo-Jonathan.” Old Testament Essays 29, no. 3 (2016a):601-32; Doi: http://dx.doi.org/10.17159/2312-3621/2016/v29n3a14, "Obadiah and a Hermeneutic of Vulnerability," in Obadiah, Readings: A New Biblical Commentary, ed. Bob Becking (Sheffield: Sheffield Phoenix, 2016), 4563 and "Responding to the Decolonial Turn: Epistemic Vulnerability," Missionalia 43, no. 3 (2015a):266-91. Doi: http://dx.doi.org/10.7832/43-3-77.

8 Emmanuel Levinas, Difficult Freedom. Essays on Judaism. Translated by Sean Hand (Baltimore: Johns Hopkins University Press, 1990), 8, 10.

9 Michal Ben-Naftali, “Abel's Look. Levinas Reads Cain,” in Levinas Faces Biblical Figures, ed. Yael Lin (New York: Lexington Books, 2014), 138.

10 Ben-Naftali, “Abel's Look. Levinas Reads Cain,” 138.

11 James W. Perkinson, White Theology. Outing Supremacy in Modernity (New York: Palgrave, 2004$), 76$.

12 Perkinson, White Theology, 77.

13 Perkinson, White Theology, 85.

14 Perkinson, White Theology, 103.

15 Perkinson, White Theology, 3.

16 The public protection of vulnerable groups in medical research became necessary after a few public scandals of unethical experimentation in the USA. See Joseph Tham, "The Principle of Vulnerability: Meeting Ground of Six Religions," in Religious Perspectives on Human Vulnerability in Bioethics. Advancing Global Ethics, ed. Joseph Tham, Alberto Garcia and Gonzalo Miranda, 2:1-8 (Dordrecht: Springer, 2014). Doi: 10.1007/97894-017-8736-9_19. Article 8 of the declaration reads as follows, "In applying and advancing scientific knowledge, medical practice and associated technologies, human vulnerability should be taken into account. Individuals and groups of special vulnerability should be protected and the personal integrity of such individuals respected."

17 Joseph Tham, "Lessons Learned," in Religious Perspectives on Human Vulnerability in Bioethics. Advancing Global Ethics, ed. Joseph Tham, (Dordrecht: Springer, 2014), 215-24. Doi: 10.1007/978-94-017-8736-9_19, distinguishes between biological, social and cultural vulnerabilities. Social vulnerability arises from war, crimes, prejudices like racism, and poverty and cultural vulnerability stems from the categorization of cultural norms and traditions in such a way that groups or individuals are rendered vulnerable. These two are based on extrinsic factors whereas biological vulnerability is based on intrinsic factors.

18 Erinn Gilson, The Ethics of Vulnerability. A Feminist Analysis of Social Life and Practice. Routledge Studies in Ethics and Moral Theory 26 (London: Routledge, 2016), 32.

19 Henk ten Have, "Vulnerability as the Antidote to Neoliberalism in Bioethics / Vulnerabilidad Como Antídoto Al Neoliberalismo En Bioética," Revista Redbioética/UNESCO 5, no. 1 (2014):87-92.

20 Ten Have, "Vulnerability as the Antidote to Neoliberalism in Bioethics," 90-1.

21 Gilson, The Ethics of Vulnerability. A Feminist Analysis, 34-35. 
more or less.

Francesca Stavrakopoulou, "The Blackballing of Manasseh," in Good Kings and Bad Kings. The Kingdom of Judah in the Seventh Century BCE., ed. Lester Grabbe T\&T Clark Biblical Studies (London: T\&T Clark, 2007), 248-9.

Andrew T. Ohm, "Manasseh and the Punishment Narrative," Tyndale Bulletin 61, no. 2 (2010):249-252 sees in the Deuteronomistic version of Manasseh's story in 2 Kings 21 a punishment narrative: (i) sin description vv. 2-3; (ii) sin development - vv. 4-8 and 16; (iii) Reminder/Prophetic intervention - vv. 10-15; (iv)

Response / climax - v.9; (v) Punishment - 2 Kings 24: death of Josiah, military defeat, destruction of cult and deportation.

Gilson, The Ethics of Vulnerability. A Feminist Analysis, 48.

Gilson, The Ethics of Vulnerability. A Feminist Analysis, 65.

Gilson, The Ethics of Vulnerability. A Feminist Analysis, 129

Gilson, The Ethics of Vulnerability. A Feminist Analysis, 94-6.

Gilson, The Ethics of Vulnerability. A Feminist Analysis, 96.

Tham, "Lessons Learned," 223.

initial proposal was in the article "Empire and the Hermeneutics of Vulnerability," SHE Suppl 37 country (cf. Areff, Ahmed. "Listen: Whites Took Nothing from No One - Pastor André Olivier."

News24.com, June 28, 2916. http://www.news24.com/SouthAfrica/News/listen-whites-took-nothing-from-noexpastor-andre-olivier-20160628). The pastor's sermon exhibits a false innocence in claiming that whites in Olivier's sermon is very much a racialised self with racial imaginations intertwined with white anxiety and fears about people who are different. These racial imaginings about the white self is one of goodwill, which is being vilified by the racial black other, communicating a particular self-importance that denies complicity in racial oppression. The sermon was countered by a response by Klippies Kritzinger (Kritzinger, Klippies (J.N.J.). "Response to Pastor André Olivier of Rivers Church, Sandton." Ahmed Kathrada Foundation, July 1, 6. http://www.kathradafoundation.org/tags/klippies-kritzinger) from the Ahmed Kathrada Foundation, in he argued that in as much as apartheid laws favoured white people, the sermon creates a false sense of (n) sermon links wealth of white people to hard work and, by implication, poverty cultural archive. Kritzinger states, "If Pastor Olivier can acknowledge complicity in the racist policies and practices that have divided our nation and oppressed the majority of its citizens for more than 360 years, then he may be able to find the humility not to be annoyed when black fellow South Africans keep on pointing out just how broken and unhealed our society still is."

Gilson, The Ethics of Vulnerability. A Feminist Analysis, 75.

See Tuana, Nancy, “The Speculum of Ignorance: The Women's Health Movement and Epistemologies of Ignorance," Hypatia 21, no. 3 (2006):1-19 in Gilson, The Ethics of Vulnerability. A Feminist Analysis, 75-77. Gilson, The Ethics of Vulnerability. A Feminist Analysis, 27.

Gilson, The Ethics of Vulnerability. A Feminist Analysis, 75.

, The Ethics of Vulnerability. A Feminist Analysis, 85.

Ten Have, "Vulnerability as the Antidote to Neoliberalism in Bioethics," 89.

Gilson, The Ethics of Vulnerability. A Feminist Analysis, 15-16.

of Vulnerability. A Feminist Analysis, 23.

Gilson, The Ethics of Vulnerability. A Feminist Analysis, 3

Gilson, The Ethics of Vulnerability. A Feminist Analysis, 55.

Stavrakopoulou, "The Blackballing of Manasseh," 249. 
50 Stuart Lasine, "Manasseh as Villain and Scapegoat," in The New Literary Criticism and the Hebrew Bible, 163-83. Journal for the Study of the Old Testament Supplement Series 143, eds. Cheryl Exum and David J.A. Clines Sheffield: Sheffield Academic Press, 1993), 166.

Stavrakopoulou, "The Blackballing of Manasseh,” 250.

52 Stavrakopoulou, “The Blackballing of Manasseh,” 252.

53 Percy S.F. van Keulen, "Manasseh through the Eyes of the Deuteronomists. The Manasseh Account (2 Kings 21:1-18) and the Final Chapters of the Deuteronomistic History." (PhD, Leiden, 1995), 145: "Notwithstanding the fact that in the Book of Kings Jerobeam, like Manasseh, is presented as the king whose sin caused the downfall of his people, Ahab is undisputedly presented as a more idolatrous king than Jerobeam." Van Keulen, "Manasseh through the Eyes of the Deuteronomists," 148.

55 Baruch Halpern, "Why Manasseh is Blamed for the Babylonian Exile. The Evolution of a Biblical Tradition," Vetus Testamentum XLVIII, no. 4 (1998):486, 489. Morton Smith, “The Veracity of Ezekiel, the Sins of Manasseh, and Jeremiah 44:18," Zeitschrift für die Alttestamentliche Wissenschaft 87, no. 1 (1975):12 sees in Manasseh's sins a reason for Josiah's death and defeat, but not the final fall of Jerusalem in 587. Stavrakopoulou, "The Blackballing of Manasseh,” 253.

57 Stavrakopoulou, "The Blackballing of Manasseh," 256.

58 Handy, "Rehabilitating Manasseh," (224) argues that the preservation of Manasseh's impieties in Chronicles but not his shedding of innocent blood relates to the function of the narrative: "A heretic can repent and make restitution, a murderous tyrant can repent, but his victims stay recalcitrantly dead."

59 Brian Kelly, "Manasseh in the Books of Kings and Chronicles (2 Kings 21:1-18; 2 Chron 33;1-20)," in Windows into Old Testament History. Evidence, Argument, and the Crisis of "Biblical Israel," (eds. V. Philips Long, David W Baker and Gordon J. Wenham (Grand Rapids: Eerdmans, 2002), 141 finds the reference to Babylon puzzling as the Assyrian capital would have been Nineveh. Perhaps the Chronicler uses Babylon here to link the eventual exile of Judah here with Manasseh's exile as a typology of what will happen.

60 Kelly, "Manasseh in the Books of Kings and Chronicles," 142, refers to the Assyrian practice of restoring rebellious vassals to their original kingdoms, as was the case with Neco I of Egypt.

61 Handy, "Rehabilitating Manasseh," 226, argues that Manasseh became the embodiment of the inhabitants of Jerusalem, their defender and not desecrator.

62 Becker, Joachim. 2 Chronik. Die neue Echter Bibel. Kommentar zum Alten Testament mit der Einheitsübersetzung. Vol. 20. (Würzburg: Echter, 1988), 111. See also Handy, "Rehabilitating Manasseh," 227.

63 Sara Japhet, I \& II Chronicles, a Commentary. Old Testament Library (London: SCM Press, 1993$), 1002$. Lasine (Lasine, "Manasseh as Villain and Scapegoat," 179) argues that Manasseh's crimes, his subsequent punishment, repentance and return exhibit what is known as a royal scapegoat. Like Oedipus, he is expelled from the community and he repents. Like Oedipus, he then brings blessings to the community before he dies. Handy, "Rehabilitating Manasseh," 228 argues that by the late Persian period Jews who took up these foreign cultic practices were no longer regarded as Jews. Those who failed to serve Judah's god were no longer regarded as Jewish.

65 Japhet, I \& II Chronicles, 1003. Handy, "Rehabilitating Manasseh," regards the idea of Manasseh having been invited to a coronation and taken as prisoner to the event as "nonsense." See Jacob M. Myers, II Chronicles. Vol. 13. The Anchor Bible (New York: Doubleday, 1965), 198-9. Myers explains the event Manasseh supposedly attended, but not the capturing with manacles, fetters, and hooks. Japhet, I \& II Chronicles, 1009.

67 Handy, "Rehabilitating Manasseh," 231.

68 Hugh Page, "Prayer of Manasseh," in The Africana Bible. Reading Israel's Scriptures from Africa and the African Diaspora, ed. Hugh Page (Minneapolis: Fortress Press, 2010), 318, says the Prayer of Manasseh is a reclamation of a king who represented "the re-embrace of leaders within the community who had at one time been classified as marginal, unacceptable, or outside of the mainstream." Josephus must also have known a version of the prayer of Manasseh in his rendition of the story. See Etienne Nodet, "Prières de Manassé (2 Chronicles 33, 1*; TSK 1.144*; 4 Q 381)," Revue Bibliques 117, no. 3 (2010):345-60 who also compares the Geniza Fragments and Qumran evidence to a Hebrew version of the prayer. 
Lowel K. Handy, "Rehabilitating Manasseh: Remembering King Manasseh in the Persian and Hellenistic Periods. Social Memory and Imagination," in Remembering Biblical Figures in the Late Persian \& Early Hellenistic Periods, eds. Diana Edelman and Ehud Ben Zvi (London: Oxford University Press, 2013), 222223. Louis H. Feldman, “Josephus’ Portrait of Manasseh,” JSP 9 (1991):4.

76 Hanna Liss, “'The Sins of the Prophets:' Biblical Characters through Rabbinic Lenses.” Lexington Theological Quarterly 37, no. 4 (2002):207.

77 Obvious Vengeyi, "King Manasseh of Judah: A Paradigm for Understanding What Lies behind Good/bad African Leadership Dichotomy," Review of Human Factor Studies 20, no. 1 (2014):101-108 provides an indepth discussion of the two texts in Prism B and C.

78 Lasine, "Manasseh as Villain and Scapegoat," 178.

79 Lasine, "Manasseh as Villain and Scapegoat," 178.

80 See Feldman, "Josephus' Portrait of Manasseh," 6-8. The angels urged God not to accept his repentance, but God replied that in not accepting him, he would be closing the door on all repentant sinners. Feldman, "Josephus' Portrait of Manasseh," 10-12.

82 Stavrakopoulou, "The Blackballing of Manasseh," 258.

83 Stavrakopoulou, "The Blackballing of Manasseh,” 257.

84 Vengeyi, "King Manasseh of Judah," 99-130.

85 Marvin A. Sweeney, "King Manasseh of Judah and the Problem of Theodicy in the Deuteronomistic History," in Good Kings and Bad Kings. The Kingdom of Judah in the Seventh Century BCE (T\&T Clark Biblical Studies, London: T\&T Clark, 2007), 266.

87 Sweeney, "King Manasseh of Judah and the Problem of Theodicy," 273.

88 Römer, L'invention de Dieu, 251.

89 Dirk Buchner, "Boshet in Jeremiah 3:24: Disenfranchisement and the Role of the Goddess in Seventh-Century Judah.” Journal of Theological Studies 59, no. 2 (2008):488. William S. Morrow, "Were There Neo-Assyrian Influences in Manasseh's Temple? Comparative Evidence from Tel-Miqne/Ekron," The Catholic Biblical Quarterly 75 (2013): 73 concludes on the basis of evidence in Ekron that Manasseh in all probability pursued indigenous practices without having to disturb the Assyrian cultic practices Judah incorporated as an Assyrian vassal. Römer, L'invention de Dieu, 285.

91 Römer, L'invention de Dieu, 286.

92 Römer, L'invention de Dieu, 287.

93 Römer, L'invention de Dieu, 288.

94 James Anderson, "Creating Dialectical Tensions: Religious Developments in Persian-Period Yehud Reflected in Biblical Texts," in Religion in the Achaemenid Persian Empire. Emerging Judaism and Trends.

Orientalische Religionen in der Antike 17 (Tübingen: Mohr Siebeck, 2016), 10-11.

98 Philip R. Davies, "Monotheism, Empire, and the Cult(s) of Yehud in the Persian Period," in Religion in the Achaemenid Persian Empire. Emerging Judaism and Trends. Orientalische Religionen in Der Antike 17 (Tübingen: Mohr Siebeck, 2016), 26.

99 Davies, "Monotheism, Empire, and the Cult(s) of Yehud in the Persian Period," 25-29. 